\title{
Phytoprotection
}

\section{An extension program for ACCase inhibitor resistance in Manitoba : A case study}

\section{Goodwin}

Volume 75, numéro 4, 1994

Herbicide Resistance Workshop - Edmonton, Alberta - 9 and 10 december 1993

Atelier sur la résistance aux herbicides - Edmonton (Alberta) - 9 et 10 décembre 1993

URI : https://id.erudit.org/iderudit/706077ar

DOI : https://doi.org/10.7202/706077ar

Aller au sommaire du numéro

Éditeur(s)

Société de protection des plantes du Québec (SPPQ)l

ISSN

0031-9511 (imprimé)

1710-1603 (numérique)

Découvrir la revue

Citer cet article

Goodwin, M. (1994). An extension program for ACCase inhibitor resistance in Manitoba : A case study. Phytoprotection, 75(4), 97-102.

https://doi.org/10.7202/706077ar
Résumé de l'article

Un programme de vulgarisation conçu pour encourager les agriculteurs à adopter la rotation des herbicides plutôt que remploi continu d'herbicides inhibiteurs de l'acétyl-CoA carboxylase a été lancé en 1991. Ce programme a grandement favorisé une prise de conscience des rotations d'herbicides au Manitoba (> 90\%). La proportion des producteurs ayant adopté la rotation des herbicides est estimée à environ $40 \%$, mais on assume que ceux qui ont adopté cette pratique ne le font encore que sur une base expérimentale. L'emploi des herbicides de ce groupe se maintient encore à des niveaux très élevés à cause de la préférence des producteurs pour ces produits et parce qu'ils sont peu enclins à employer des solutions alternatives. 


\title{
An extension program for ACCase inhibitor resistance in Manitoba: A case study
}

\author{
Mark Goodwin ${ }^{1}$
}

Received 1993-10-14; 1994-07-11

An extension program designed to encourage farmers to adopt herbicide rotation in favor of continuous use of acetyl-CoA carboxylase inhibitor herbicides was launched in 1991. The program has led to high levels of awareness of herbicide rotation in Manitoba (>90\%). Adoption of herbicide rotation is estimated at approximately $40 \%$, but producers who have started to rotate herbicides are assumed to be doing so on a limited "trial" basis. The use of this group of products continues at high levels due to a combination of producer preference for these chemicals and of reluctance to use alternatives.

Goodwin, M. 1994. Un programme de vulgarisation pour la résistance aux herbicides inhibiteurs de l'ÁCCase au Manitoba: Étude de cas. PHYTOPROTECTION 75 (Suppl.): 97-102.

Un programme de vulgarisation conçu pour encourager les agriculteurs à adopter la rotation des herbicides plutôt que l'emploi continu d'herbicides inhibiteurs de l'acétyl-CoA carboxylase a été lancé en 1991. Ce programme a grandement favorisé une prise de conscience des rotations d'herbicides au Manitoba (>90\%). La proportion des producteurs ayant adopté la rotation des herbicides est estimée à environ $40 \%$, mais on assume que ceux qui ont adopté cette pratique ne le font encore que sur une base expérimentale. L'emploi des herbicides de ce groupe se maintient encore à des niveaux très élevés à cause de la préférence des producteurs pour ces produits et parce qu'ils sont peu enclins à employer des solutions alternatives.

Nomenclature of chemical names cited in the text:

Diclofop: (士)-2-[4-(2,4-dichlorophenoxy)phenoxy]propanoic acid; sethoxydim: 2-[1(ethoxyimino)butyl]-5-[2-(ethylthio)propyl]-3-hydroxy-2-cyclohexen-1-one;fenoxaprop: (士)-2[4-[(6-chloro-2-benzoxazolyl)oxy]phenoxy]propanoic acid.

\section{INTRODUCTION}

On 11 July 1990, a patch of wild oats (Avena fatua L.) was discovered near Swan River, Manitoba $\left(51^{\circ} 05^{\prime} \mathrm{N}\right.$ $\left.101^{\circ} 10^{\prime} \mathrm{W}\right)$, that had withstood repeated annual use of field rates of acetyl-CoA carboxylase (ACCase) inhibiting grasskillers, i.e. diclofop, sethoxydim, and fenoxaprop.

1. Manitoba Agriculture, Soils and Crops Branch, Box 1149, Carman, Manitoba, Canada ROG OJO 
Seed from this patch were collected and, in subsequent testing by the University of Manitoba, were found to be resistant to a number of different commonly used ACC-ase inhibiting grass-killers. Levels of resistance varied from product to product, but in all cases, this population of wild oats withstood rates which were far above economically viable field rates (Heap et al. 1993). Similar patches were found in 12 other fields in the Swan River area over the next several weeks. Although ACCase-resistant wild oats were present in only a small number of fields at that point in time, the existence of the phenomenon was a great concern for three reasons.

First, past experience with weed resistance episodes has shown that growth of the problem can be relatively rapid. For example, it took only three seasons for dinitroaniline resistance in green foxtail [Setaria viridis (L.) Beauv.] in southwestern Manitoba to go from approximately 30 documented cases, to being present in approximately 1 field in 4 in the region (B. Gibbs, personal communication). Only $7 \mathrm{yr}$ elapsed between first discovery of triazine resistance in fields in southwestern Ontario, to its presence on 260000 ha in the area (Stephenson et al. 1990).

Second, the ACCase-inhibiting grasskillers have been relied upon heavily in Manitoba owing to their dual green foxtail/wild oats activity. Approximately $70 \%$ of sprayed surfaces of major crops was treated with an ACCase inhibitor in 1991. Historical patterns of herbicide use in the province indicate a trend towards increasing use of ACCase products by farmers.

Third, ACCase inhibitors form an important part of soil conservation practices in the province. Use of these products has supplanted much of the soil-incorporated product mixes which were previously used to control wild oats, and to a lesser degree, green foxtail, on erosion-prone soils. Loss of effectiveness of these products on a large scale would seriously set back soil conservation practices such as reduced or zero tillage.

\section{MATERIALS AND METHODS}

A "needs assessment" conducted in the fall of 1990 determined that an extension effort in the area of weed resistance was required. The assessment further determined that such an effort should focus on sound agronomic practices which would delay the onset of herbicide resistance on farm fields that did not yet have the problem. Three specific extension needs were identified: a need to address the complexity of the principles surrounding the issue; a need for extremely rapid uptake and adoption of resistance management techniques among farmers if the problem was to be effectively managed prior to its developmerit on a wide scale; and a need for on-going monitoring of the extension program.

\section{Issue of complexity}

The complexity of the issue is exemplified by the fact that there were few or no lay terms to describe the processes involved in the development of weed resistance. Few or no extension terms exist for describing modes of action of herbicides, or the processes involved in selection pressure on population genetics within a field. Accordingly, a set of standard extension terms was developed through cooperative work between university, industry and provincial extension staff across the Prairies. A classification scheme of herbicides according to modes of action was developped by Manitoba Agriculture (1993), and a modified version of this scheme is presented in these proceedings by Morrison and Devine (1994). Extension terminology was developed to describe terms such as selection pressure and initial frequency as well.

\section{Need for rapid adoption}

Rapid adoption of weed resistance management strategies was deemed to be important because of past experiences with the problem. Classical rural extension studies have shown that full adoption of new thoughts, techniques or innovations follows an S-curve referred to as the adoption continuum (Rogers 1962). The time lag between first introduction of a new technique 
until full adoption by the farm community is usually a number of years. At the same time, prior experience with the development of important resistance relationships has shown that there is a relatively short time span between first discovery of a problem, and the problem becoming endemic. To facilitate rapid adoption of weed resistance management techniques, an aggressive extension effort was launched within 6 mo of the discovery of the first patch of ACCase-resistant wild oats.

Emphasis was placed on herbicide rotation as a first step towards managing the problem because adoption of herbicide rotation was considered to be a less disruptive change for farmers than more basic integrated weed management techniques. As such, it was felt that herbicide rotations might be adopted readily, and could serve to delay the resistance process enough to allow more time for more basic weed control extension in the area of integrated weed management. A classic study on the adoption of hybrid corn in lowa in the 1950s showed that effective adoption follows a two-step process: first, adoption by early innovators who usually adopted on the advice of sales persons; and second, adoption by early majority producers, who adopted the practice after watching the early adopters (Rogers 1962). To facilitate the implementation of the first step, it was important to include dealers and manufacturers as important partners in disseminating herbicide rotation information. Taking these objectives and problems into account, a three-phase extension plan involving input from the private sector, the University of Manitoba and public sector extension personnel was started in January 1991 (Table 1).

\section{Monitoring}

Monitoring of farmer's attitudes towards resistance was conducted through four random surveys of growers (1991), dealers (1992 and 1993), and municipal weed supervisors (1993). Additionally, numbers of new documented cases of resistance and herbicide use statistics were monitored. The survey of growers was conducted through personal interviews with 15 randomly selected producers from the Somerset area of Manitoba $\left(49^{\circ} 27^{\prime} \mathrm{N} 98^{\circ} 40^{\prime} \mathrm{W}\right)$. Producers were asked to complete a questionnaire which tested their understanding of resistance. These results were examined to determine where gaps of understanding were occurring.

The 1992 and 1993 dealer surveys were conducted by randomly selecting 20 dealers in 1992 and 20 dealers in

Table 1. Phases of implementation of a herbicide resistance management extension program in Manitoba

\begin{tabular}{ll}
\hline Goals & Steps of implementation \\
\hline Phase I - Awareness Program (Jan. 1991 - May 1992) \\
- Generate awareness of resistance & 1. Agreement and adoption of \\
- Promote understanding of how & standardized terms \\
resistance develops & 2. Contribution to dealer schools \\
- Prepare agricultural infrastructure & 3. Promotion of awareness by farm \\
(dealer training, staff workshops) & meeting programs \\
& \\
Phase II - Adoption/Promotion Program (Jan. 1993 - May 1993) \\
- Increase adoption of herbicide rotation & 1. Run "neighbor" program \\
amongst farmers & 2. Dispense information through farm press \\
& 3. Provide support to dealers
\end{tabular}

Phase III - Integrated approach (Jan. 1994 - ...)

- Promote integrated weed

1. Weedsystems 2000 management techniques 
1993, from the list of licensed dealers compiled by Manitoba Agriculture. These surveys were conducted by telephone, and requested dealers' opinions on the percentage of farmers in their trading area who were aware of weed resistance, and on the percentage of farmers who had made a herbicide purchase decision based on rotation. These results were used to monitor status of adoption. The 1993 survey of 31 weed supervisors requested information on their perception of factors preventing producers from adopting herbicide rotation. The supervisors were asked to report the two major reasons for which producers were not rotating herbicides in their districts. Responses from this survey were reviewed to determine what factors were preventing non-adopters from using herbicide rotation on their farms.

\section{RESULTS AND DISCUSSION}

The grower survey conducted in the summer of 1991 showed that after one winter of resistance extension through media and farm meetings, producers were beginning to become familiar with basic principles surrounding how resistance occurs and the management principles for coping with the problem (Table 2). Most knew that herbicide rotation was a first step towards dealing with the problem. However, almost half of farmers surveyed experienced difficulty in identifying products by herbicide group.
Accordingly, more effort was expended on explaining modes of action during the winter of 1991-1992 and attempting to promote herbicide rotation. A dealer survey conducted in summer of 1992 showed that $67 \%$ of producers were aware of the problem, but that the number of producers practicing herbicide rotation was still only about $12 \%$ (Fig. 1). A number of dealers commented that producers who were outside of the Swan River Valley (where the initial problems occurred) did not believe it to be a problem because of the lack of cases in their areas.

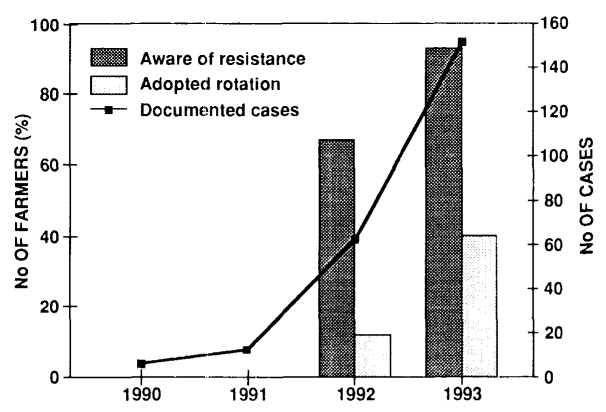

Figure 1. Awareness of resistance and adoption of herbicide rotations by farmers, paralleled to the total number of known cases of herbicide resistance in Manitoba.

By January 1993, the number of ACCase-resistant wild oats cases exceeded 100 fields and had been documented province-wide (Fig. 1). Some cases of ACCase resistance in

Table 2. Comprehension of resistance issues by 15 farmers of southern Manitoba ${ }^{a}$

\begin{tabular}{lc}
\hline Aspects of resistance inquired & $\begin{array}{c}\text { Number of } \\
\text { producers }^{b}\end{array}$ \\
\hline Comprehend that repeated use of same chemical causes resistance & 10 \\
Understood link between resistance and genetics & 1 \\
Able to define what a herbicide group is & 12 \\
Understood that resistance to one product within a group could lead & 11 \\
to resistance to other products in that group & 8 \\
Able to match herbicides into groups using printed extension material & \\
\hline a Treherne (Somerset) area, $49^{\circ} 40^{\prime} \mathrm{N} 98^{\circ} 50^{\prime} \mathrm{W}$. & \\
b Total number of farmers surveyed: 15. &
\end{tabular}


green foxtail were found as well. Major dealerships, some manufacturers, and front line extension staff organized in excess of 50 meetings over the next 3 mo specifically devoted to the subject of weed resistance management. In an effort to make the problem seem less abstract, extension efforts highlighted the troubles faced by neighbours who had developed resistance problems on their farms. Higher levels of adoption of herbicide rotation were noted the following season. The 1993 survey of dealers indicated that approximately 4 farm customers out of 10 had made a herbicide purchase based in whole or in part on resistance management. The same survey indicated that awareness levels had reached very high levels, i.e. above $90 \%$ (Fig. 1).

These adoption levels are confirmed by herbicide use statistics for Manitoba (Fig. 2.). Figures show a slowing of the increase in use of ACCase inhibitors on major crops in Manitoba, but the use of these products for wild oats and green foxtail control in the province continued to dominate herbicide usage in 1993. It may be that producers who are rotating herbicides have only done so on a limited number of hectares. This would explain the fact that high adoption levels reported are not supported by use statistics. Compiled responses from weed supervisors in the 1993 survey list the major reasons for non-adoption of herbicide rotation (Table 3). The most cited reasons for producers persisting in the continuous use of group 1 herbicides related to their preference for the efficacy of these products. Weed supervisors indicated that farmers showed strong preference for the one-pass wild oats/green foxtail control, the tank mixability of the products, and the high efficacy across a wide range of leaf stages.

Out of 31 weed supervisors, 16 reported that farmers in their districts had wanted to rotate chemicals but felt they couldn't. One major obstacle cited was varietal restrictions. A number of wheat (Triticum aestivum L.) varieties commonly grown in the province are prone to crop injury due to non-group 1 products. A second obstacle to rotation was the fact that the weather in the fall of 1992 did not permit the use of non-group 1 soil-incorporated products. A third obstacle to rotation was lack of

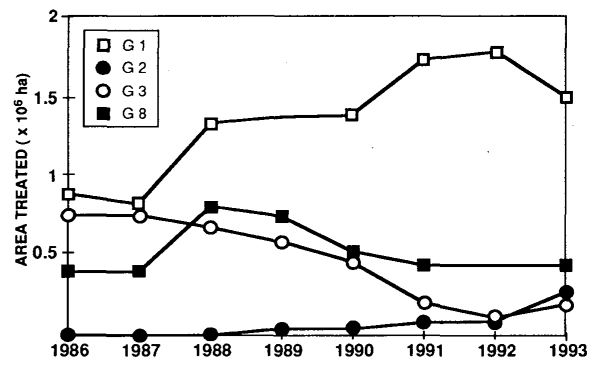

Figure 2. Relative importance of four herbicide groups in Manitoba, in terms of surfaces treated over a 7-yr period. G1: group 1; G2: group 2; G3: group 3; G8: group 8 .

Table 3. Reasons for non-adoption of herbicide rotation among Manitoba producers ${ }^{\mathrm{a}}$

\begin{tabular}{lc}
\hline Reason & $\begin{array}{c}\text { Number of times } \\
\text { cited }\end{array}$ \\
\hline
\end{tabular}

Do not rotate because group 1 products are better than alternatives

(high efficacy, wide staging, dual green foxtail/wild oats control) 14

"It can't happen to me" syndrome $\quad 9$

Non-group 1 products do not perform well enough $\quad 5$

Wanted to rotate but had no satisfactory options in oilseeds or special crops 8

Wanted to rotate but could not because of crop varietal restrictions $\quad 3$

Wanted to rotate but could not because of lack of time for fall-applied alternatives

Wanted to rotate but dealer ran out of supply of alternatives

a Based on a survey of 31 municipal weed supervisors. 
non-group 1 grasskillers for use in oilseeds such as flax (Linum usitatissimum L.) or special crops such as buckwheat (Fagopyrum esculentum Moench). Out of 31 weed supervisors, 9 reported that farmers felt that weed resistance "couldn't happen" in their farming region. At the present time, the number of documented cases of resistance continues to increase.

Extension staff are currently developing an integrated weed management package to be called Weedsystems 2000. The package is intended to assist farmers in lessening dependency on herbicides, regardless of whether they are doing so to prevent weed resistance problems, or to cope with the problem after it has developed.

\section{REFERENCES}

Anonymous. 1993. Guide to crop protection. Manitoba Agriculture. 193 pp.

Heap, I.M., B.G. Murray, H.A. Loeppky, and I.N. Morris. 1993. Resistance to aryloxyphenoxypropionate and cyclohexanedione herbicides in wild oat (Avena fatua). Weed Sci. 41: 232-238.

Morrison, I.N., and M.D. Devine. 1994. Herbicide resistance in the Canadian Prairie provinces: Five years after the fact. Phytoprotection 75 (Suppl.): 5-16.

Rogers, E. 1962. The adoption process. Diffusion of innovations. Collier MacMillan Ltd.

Stephenson, G.R., M.D. Dykstra, R.D. McLaren, and A.S. Hamill. 1990. Agronomic practices influencing triazineresistant weed distribution in Ontario. Weed Technol. 4: 199-207. 